\title{
DNA-Chitosan Bilayer Membrane as a Bi-functional Biomedical Adhesive
}

\author{
Satoshi RiKimaru, Yoko WaKabaYashi, Motoyoshi NomizU, \\ and Norio NISHI ${ }^{\dagger}$ \\ Laboratory of Bio-Material Chemistry, Division of Bioscience, Graduate School of \\ Environmental Earth Science, Hokkaido University, \\ Kita-ku, Sapporo 060-0810, Japan
}

(Received September 3, 2002; Accepted December 2, 2002)

\begin{abstract}
DNA-chitosan bilayer membranes were designed and prepared as a biomedical adhesive for therapeutic application. Various DNA-chitosan bilayer membranes were prepared by applying chitosan solution $\left(2.0 \mathrm{mg} \mathrm{cm}^{-2}\right)$ on UV-irradiated DNA membranes $\left(0.2-0.5 \mathrm{mg} \mathrm{cm}^{-2}\right)$. Tensile strengths of the DNA-chitosan bilayer membranes were approximately $4.0 \mathrm{~N}$ similar to that of chitosan alone membrane $2.0 \mathrm{mg} \mathrm{cm}^{-2}$. These results indicate that the bilayer membranes have enough tensile strength as a surgical tape. When the surface of the DNA-chitosan membranes was analyzed using a scanning electron microscope (SEM), fiber-like structure was observed on the DNA-side of the DNA-chitosan membranes, prepared from more than $0.3 \mathrm{mg} \mathrm{cm}^{-2}$ of UV-irradiated DNA membranes. In contrast, the chitosan-side of the DNA-chitosan membranes showed a smooth surface similar to that of the chitosan alone membrane. These results indicated that a DNA-chitosan bilayer membrane was successfully prepared using UV-irradiated DNA membranes $(0.3-$ $\left.0.5 \mathrm{mg} \mathrm{cm}^{-2}\right)$ and chitosan $\left(2.0 \mathrm{mg} \mathrm{cm}^{-2}\right)$. Next, we observed bonding strength of the membranes to rabbit peritoneum. The bonding strength of the chitosan-side was similar to that of fibrin glue. On the other hand, DNA side of bilayer membrane did not adhere to the peritoneum. The DNA-chitosan membrane is bi-functional and has a potential to serve as a bi-functional bio-adhesive.

KEY WORDS DNA / Chitosan / Polyion / Complex / Bilayer Membrane / Bio-adhesive /
\end{abstract}

Chitin is a mucopolysaccharide composed of $N$ acetyl-D-glucosamine by $\beta(1 \rightarrow 4)$ glycoside linkage and presents in the nature as outside skeleton of crustaceans, cell wall of bacteria, and insects. ${ }^{1}$ Chitosan, deacetylated chitin, has diverse specific functions including wound healing, hemostasis and antibiosis. ${ }^{2-4}$ Chitosan is biodegradable and non-toxic. ${ }^{5,6}$ Therefore, chitosan has been used as medical materials. 2,7

DNA, one of the most important materials for life processes, can be regarded as a naturally occurring and highly specific functional biopolymer. Previously, we have described a preparation of water-insoluble DNA membrane by UV-irradiation. The UV-irradiated DNA film was resistant to nuclease and biochemically stable. $^{8}$ The UV-irradiated DNA retained the double stranded structure and the DNA specific properties. ${ }^{8}$ Additionally, the UV-irradiated DNA membrane accumulated DNA-intercalating compounds and endocrine disruptors with planar structures, such as ethidium bromide, dibenzo- $p$-dioxin, dibenzofuran, biphenyl, and benzo $[a]$ pyrene. ${ }^{9}$

Medical adhesives are used for tissue adhesion, hemostasis, sealing of leakage of air, and body fluids surgical procedures. Various biomedical adhesives, such as cyanoacrylate polymer, fibrin glue, chemically crosslinkable gelatin, and photo-crosslinkable chitosan, have been developed. ${ }^{10,11}$ Cyanoacrylate polymer has connected the organs by the strong adhesion on wet surface of tissue, however, it has serious drawbacks to be obstructive the progress of wound healing by hard solid and also to produce formaldehyde by degradation of cyanoacrylate. ${ }^{12,13}$ Although fibrin glue using blood coagulation systems containing fibrinogen, thrombin, factor XIII, and protease inhibitor, has been attracted as a friendly suture material for body, it has been reported on risky infection, because it originated from the blood of human and cattle. ${ }^{14-17}$

It was reported that the chitosan membrane adheres to tissue. ${ }^{18-20}$ The chitosan membrane may be used as the tape adhering to tissue at surgical operation. However, when the chitosan membrane is used as a surgical tape adhering to tissue, it causes adhesion to not only the wounded part but also to other side. As a result, the chitosan membrane would unstick wounded part, and then mutual conglutination of the wounded part would occur.

Here, we designed and prepared a bilayer membrane using chitosan and DNA to develop a bi-functional biomedical material. The physical properties including bilayer structure and strength were also evaluated.

${ }^{\dagger}$ To whom correspondence should be addressed(Phone/FAX: +81-11-706-2256, E-mail: nishin@ees.hokudai.ac.jp). 


\section{EXPERIMENTAL PROCEDURES}

\section{Materials}

Double stranded DNA (Na salt from salmon sperm, $M_{\mathrm{w}}=5 \times 10^{6} \sim$ ) was purchased form Yuki Fine Chemical Co. Ltd, Tokyo, Japan. Fibrin glue (Beriplast ${ }^{\mathbb{R}}$ ) was purchased from Aventis Pharma Ltd, Tokyo, Japan, and used as a control. The chitosan $62(62 \%$ degree of deacetylation, $M_{\mathrm{v}}=1.1 \times 10^{6}$ ) was purchased form Fuji Spinning Co., Ltd. Tokyo, Japan. ${ }^{21}$ Commercial chitosans [chitosan 7B $(70 \%$ degree of deacetylation) and chitosan 100 (80\% degree of deacetylation)] purchased from Funakoshi Co. Ltd., Tokyo, Japan and Wako Pure Chemical Industries, Ltd. Osaka, Japan were also used. The Viscosity-average molecular weights of chitosans are in the $M_{\mathrm{v}}=2.9 \times 10^{6}$ and $6.3 \times 10^{5} .{ }^{21}$ All reagents were purchased from Wako Pure Chemical Industries, Ltd., Osaka, Japan.

\section{Preparation of Chitosan Membrane}

Various amounts of chitosan 4\% acetic acid solution $\left(10 \mathrm{mg} \mathrm{mL}^{-1}, 4.0-24 \mathrm{~mL}\right)$ was applied onto a Teflon ${ }^{\circledR}$ plate $\left(6 \times 13 \mathrm{~cm}^{2}\right)$ and dried overnight at room temperature. The resulting chitosan membrane $\left(0.5-3.0 \mathrm{mg} \mathrm{cm}^{-2}\right)$ was rinsed with $0.5 \mathrm{M} \mathrm{NaOH}-80 \%$ methanol solution and methanol (2 times), and then dried in vacuum desiccator.

\section{Preparation of DNA-chitosan Bilayer Membrane}

Various amounts of DNA aqueous solution (5 $\mathrm{mg} \mathrm{mL}^{-1}, 3.1-7.8 \mathrm{~mL}$ ) were applied onto a glass plate $\left(6 \times 13 \mathrm{~cm}^{2}\right)$ and dried overnight at room temperature. The DNA membrane was insolubilized by UV irradiation of $254 \mathrm{~nm}$ with $5600 \mu \mathrm{W} \mathrm{cm}{ }^{-2}$ for $6 \mathrm{~h}$ as described previously. ${ }^{8}$ A chitosan solution $\left(10 \mathrm{mg} \mathrm{mL}^{-1}\right.$, $15 \mathrm{~mL}$ ) was applied onto the UV-irradiated DNA membrane $\left(6 \times 13 \mathrm{~cm}^{2}\right)$ and dried overnight at room temperature. The resulting DNA-chitosan membrane was stripped from the glass plate by immersion to ethanol and rinsed with $0.5 \mathrm{M} \mathrm{NaOH}-80 \%$ methanol solution and methanol. Then, the membrane was dried in vacuum desiccator.

\section{Tensile Properties of Membranes}

Membranes were cut into $5 \times 1 \mathrm{~cm}^{2}$ and were swollen with saline. Tensile strength was measured using a tensile machine (EZ-Test, Shimadzu Co., Kyoto, Japan) at separation rate of $10 \mathrm{~mm} \mathrm{~min}^{-1}$. The tensile strength was expressed by an average of six measurements, with a standard deviation of the mean (S.D.).

\section{Amount of DNA in the Bilayer Membranes}

DNA-chitosan membrane $\left(1 \times 1 \mathrm{~cm}^{2}\right)$ was incubated with water for $24 \mathrm{~h}$ and gently washed with water $(2$ times). Then the membrane was hydrolyzed with $1 \mathrm{M}$ $\mathrm{HCl}$ solution $(1 \mathrm{~mL})$ at $100^{\circ} \mathrm{C}$ for $1 \mathrm{~h}$ and the amount of DNA was determined from the UV absorbance $(260 \mathrm{~nm})$ of the solution..$^{22} \mathrm{UV}$ absorbance of solution was measured using a UV-Vis spectrophotometer (U2000A, Hitachi Co., Ltd., Tokyo, Japan).

\section{SEM Analysis of Membranes}

DNA, chitosan, and DNA-chitosan membranes were incubated with water for $24 \mathrm{~h}$ and freeze-dried. The dried membranes were coated with gold at $8 \mathrm{~mA}$, $1200 \mathrm{~V}$ for 4-5 min using ion sputter (JFC-1100, JOEL Ltd. Tokyo, Japan). Then surface and cross-section of the membranes were observed using a scanning electron microscope (SEM) at $8.0 \mathrm{kV}$ (S-2400, Hitachi Co., Ltd., Tokyo, Japan).

\section{Swelling Ratio of Membranes}

The membranes were dried under vacuum and their dry weights were measured (approximately $2.07 \pm 0.73 \mathrm{mg}, 1 \times 1 \mathrm{~cm}^{2}$ ). The dry membranes were immersed again in ultra pure water at $25^{\circ} \mathrm{C}$ for various times and wiped with Kimwipe ${ }^{\circledR}$, then their wet weights were measured. Swelling ratio of membranes was calculated from the following equation (eq 1). The swelling ratio was expressed by an average of three measurements, with a S.D. of the mean.

$$
\begin{aligned}
& \text { Swelling ratio }(\text { wt } \%) \\
& =[(\text { wet weight }- \text { dry weight }) / \text { dry weight }] \\
& \quad \times 100
\end{aligned}
$$

Bonding Strength of the DNA-Chitosan Membrane to Rabbit Peritoneum

Rabbit peritoneum (buck Japanese white, weighting $2-2.5 \mathrm{~kg}$ ) was donated from Kuraray Co. Ltd., Osaka, Japan. Fresh rabbit peritoneum was stocked at $-20^{\circ} \mathrm{C}$. Thawed rabbit peritoneum $(3 \times 1 \mathrm{~cm})$ was immersed in saline. A dry membrane $(3 \times 1 \mathrm{~cm})$ was placed on the peritoneum with a bonding area of $1 \times 1 \mathrm{~cm}$. After 2 min, bonding strength was measured using a tensile machine (Autograph; Shimadzu Inc., Kyoto, Japan) at a separation rate of $10 \mathrm{~mm} \mathrm{~min}^{-1}$. The bonding strength was expressed by an average of five measurements, with a S.D. of the mean.

\section{Ethidium Bromide Staining of Membranes}

The chitosan and DNA-chitosan membranes $\left(1 \times 1 \mathrm{~cm}^{2}\right)$ were immersed in ultra pure water at room 


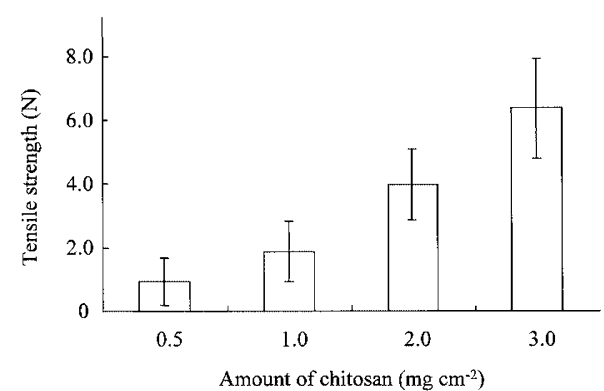

Figure 1. Tensile strength of chitosan membranes. Various chitosan membranes $\left(0.5-3.0 \mathrm{mg} \mathrm{cm}^{-2}\right)$ were swollen with saline and the tensile strength was measured. The tensile strength was expressed by an average of 6 measurements (means \pm S.D.).

temperature for $24 \mathrm{~h}$ and incubated with ethidium bromide solution $\left(20 \mu \mathrm{g} \mathrm{mL}^{-1}\right)$. After $24 \mathrm{~h}$, the membranes were removed from staining solution and washed with ultra pure water, then the membranes were observed under UV illumination. The DNA-chitosan membranes were observed fluorescence from UV-irradiated $(366 \mathrm{~nm})$ membranes.

\section{RESULTS AND DISCUSSION}

Various chitosan membranes $\left(0.5-3.0 \mathrm{mg} \mathrm{cm}^{-2}\right)$ were prepared and their tensile strengths were determined to optimize chitosan amount for the bilayer membrane (Figure 1). When the amount of chitosan was increased from 0.5 to $3.0 \mathrm{mg} \mathrm{cm}^{-2}$ the tensile strength increased. Previously, more than $3.0 \mathrm{~N}$ of tensile strength was suggested to be required for a membrane to use as a surgical tape. The tensile strength of more than $2.0 \mathrm{mg} \mathrm{cm}^{-2}$ chitosan membranes showed higher than $3.0 \mathrm{~N}$ indicating to have a potential to use for a surgical tape. ${ }^{10}$ Based on the results, we used $2.0 \mathrm{mg} \mathrm{cm}^{-2}$ chitosan membrane for further experiments.

Chitosan solution $\left(10 \mathrm{mg} \mathrm{mL}^{-1}, 4.0-24 \mathrm{~mL}\right)$ was casted on various amounts of UV-irradiated DNA membranes $\left(6 \times 13 \mathrm{~cm}^{2}\right)$ and prepared DNA-chitosan bilayer membranes. When amounts of DNA applied for preparation of membranes increased $(0.2-$ $0.5 \mathrm{mg} \mathrm{cm}^{-2}$ ), the DNA contents of the bilayer membranes slightly increased $\left(0.1-0.15 \mathrm{mg} \mathrm{cm}^{-2}\right)$ (Figure 2). Thus, the amounts of DNA in DNA-chitosan membrane can be controlled but the efficiency was low. The low efficiency of insolubilized DNA amount may be due to the low degree of cross-linking by the UVirradiation treatment.

We also determined tensile strength of the DNAchitosan bilayer membranes (Figure 3). Tensile strength of the all DNA-chitosan bilayer membranes was approximately $4.0 \mathrm{~N}$ similar to that of $2.0 \mathrm{mg} \mathrm{cm}^{-2}$

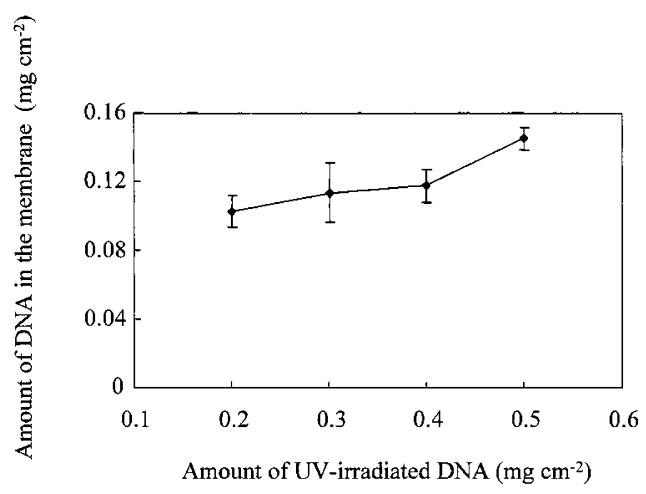

Figure 2. Amount of DNA in DNA-chitosan membranes. DNA-chitosan membrane was incubated with water for $24 \mathrm{~h}$ and gently washed with water. Then the membrane was hydrolyzed with $1 \mathrm{M} \mathrm{HCl}$ at $100^{\circ} \mathrm{C}$ for $1 \mathrm{~h}$. The absorbance of the solution at $260 \mathrm{~nm}$ was measured and amount of DNA was determined. The experiments were expressed by an average of 3 measurements (means \pm S.D.).

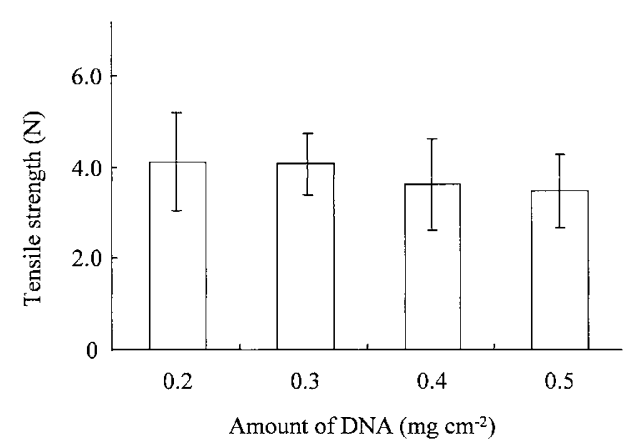

Figure 3. Tensile strength of DNA-chitosan membranes. DNA-chitosan membranes $\left(2.0 \mathrm{mg} \mathrm{cm}^{-2}\right.$ of chitosan) were swollen with saline and the tensile strength was measured. The tensile strength was expressed by an average of 6 measurements (means \pm S.D.).

chitosan membrane. These results indicate that the DNA does not significantly affect on the tensile strength of the bilayer membranes. Furthermore, DNAchitosan mixed membrane was similarly prepared from mixture of DNA and chitosan solution. Tensile strength of DNA-chitosan mixed membrane was lower and fragile (data not shown). The DNA-chitosan bilayer membranes were suggested to have enough tensile strength as a surgical tape. ${ }^{10}$

Next, we observed the surface of the DNA-chitosan membranes using a SEM (Figure 4). The UV-irradiated DNA membrane showed fiber-like surface structure (Figure $4 \mathrm{Va}$ and $\mathrm{Vb}$ ). Fiber-like structure was observed on the DNA-side of the DNA-chitosan membranes, when more than $0.3 \mathrm{mg} \mathrm{cm}^{-2}$ of UV-irradiated DNA was used (Figure 4 II-IV). While, when the DNA-chitosan membrane was prepared using less than $0.3 \mathrm{mg} \mathrm{cm}^{-2}$ of DNA membranes, the fiber-like structure was not observed on the DNA-side (Figure 4 Ia and Ib). In contrast, chitosan membrane showed a smooth 


\section{DNA-side of DNA-chitosan membrane}
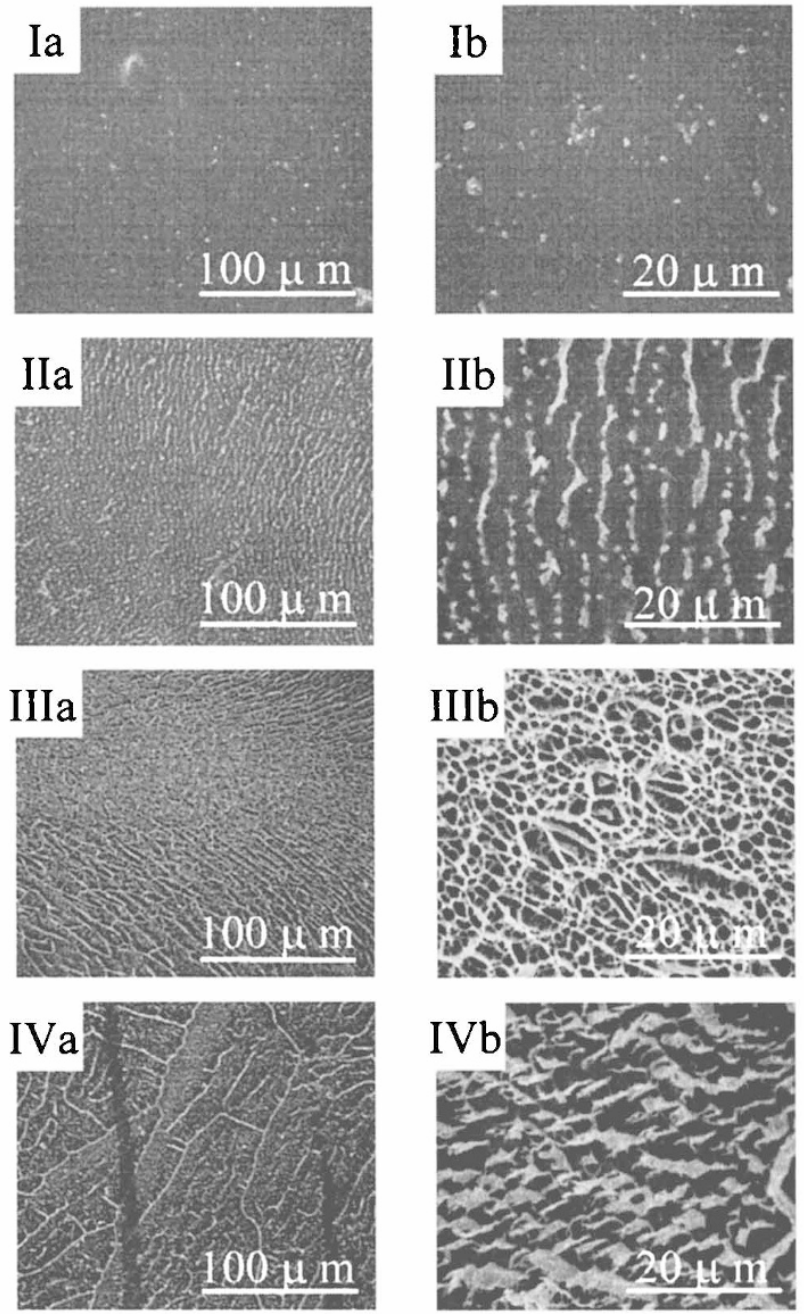

UV-irradiated DNA membrane
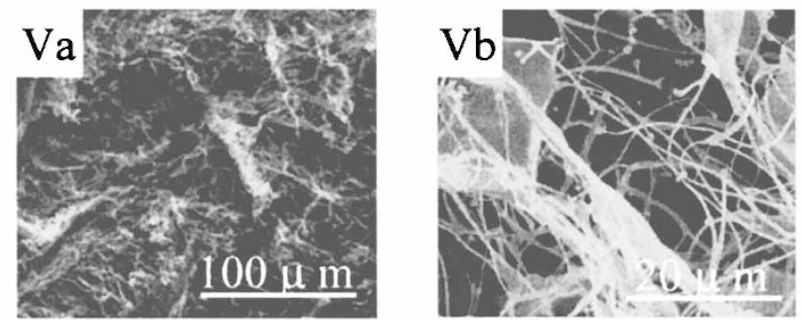

Chitosan-side of DNAchitosan membrane
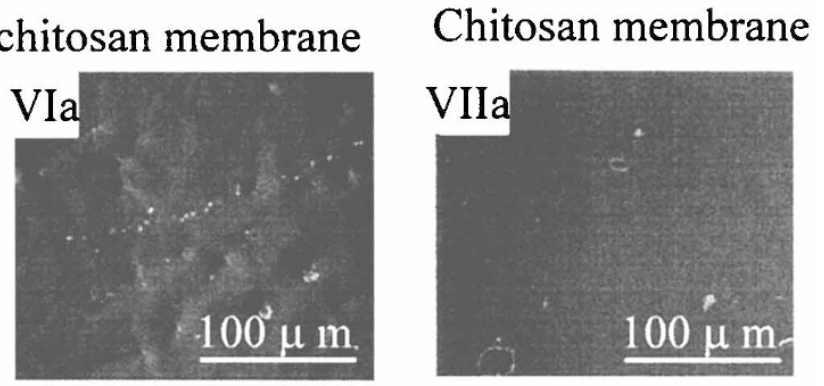

Figure 4. SEM image of DNA-chitosan, UV-irradiated DNA, and chitosan membranes. Amount of DNA, I: $0.2 \mathrm{mg} \mathrm{cm}^{-2}$, II: $0.3 \mathrm{mg} \mathrm{cm}^{-2}$, III: $0.4 \mathrm{mg} \mathrm{cm}^{-2}$, IV: $0.5 \mathrm{mg} \mathrm{cm}^{-2}$. V: UV-irradiated DNA membrane, VI: chitosan-side of DNA-chitosan membrane (DNA: $0.4 \mathrm{mg} \mathrm{cm}^{-2}$ ), VII: chitosan membrane. a: low magnification $(\times 300)$, b: high magnification $(\times 1,500)$.
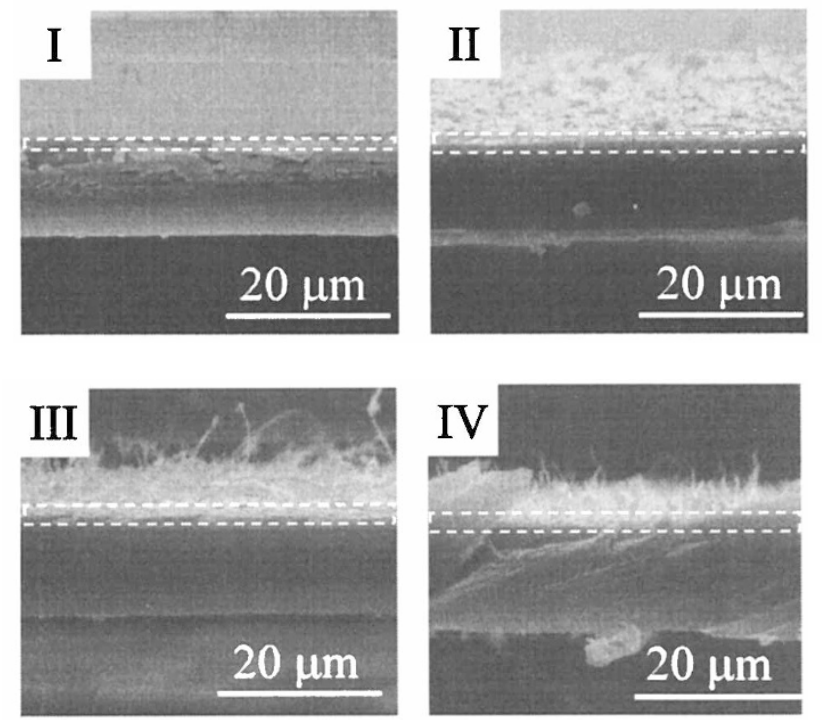

Figure 5. SEM image of a cross-section of DNA-chitosan bilayer membranes. Amount of DNA, I: $0.2 \mathrm{mg} \mathrm{cm}^{-2}$, II: $0.3 \mathrm{mg} \mathrm{cm}^{-2}$, III: $0.4 \mathrm{mg} \mathrm{cm}^{-2}$, IV: $0.5 \mathrm{mg} \mathrm{cm}^{-2}(\times 1,500)$. DNA layers are indicated by a broken line circle.

surface structure (Figure 4 VIIa). The chitosan-side of all the DNA-chitosan membranes showed a smooth surface structure similar to that of chitosan membrane (Figure $4 \mathrm{VIa}$ ). We also observed the cross-section of the bilayer membranes (Figure 5). Fiber-like structure was clearly observed on the DNA-side of the bilayer membranes prepared from more than $0.3 \mathrm{mg} \mathrm{cm}^{-2}$ of UV-irradiated DNA. Although amounts of DNA of the bilayer membranes increased $\left(0.2-0.5 \mathrm{mg} \mathrm{cm}^{-2}\right)$ in Figure 2., the thickness of the fiber-like DNA was not significantly increased (Figure 5 broken line circle). These results indicated that a DNA-chitosan bilayer membrane was successfully prepared using UVirradiated DNA membranes $\left(0.3-0.5 \mathrm{mg} \mathrm{cm}^{-2}\right)$ and chitosan $\left(2.0 \mathrm{mg} \mathrm{cm}^{-2}\right)$, and also consisted of DNA and chitosan surfaces.

We determined swelling ratio of DNA-chitosan membrane (Figure 6). All membranes swelled quickly in water. Swelling ratios of all the membranes reached to a constant value after $1 \mathrm{~min}$ and did not change after $24 \mathrm{~h}$. The swelling ratio of DNA-chitosan membrane was lower than that of chitosan membrane. These results indicate that chitosan-side of DNA-chitosan membrane may be quickly adhered to tissue, since the chitosan-side of membrane rapidly absorbs water on the organ.

Next, we tested, the bonding strength of the membranes to rabbit peritoneum (Table I). Chitosan 80 membrane adhered to rabbit peritoneum with a bonding strength of $0.46 \pm 0.23 \mathrm{~N} \mathrm{~cm}^{-2}$. The bonding strength of the chitosan-side of the bilayer membranes increased $\left(0.06 \pm 0.03-0.47 \pm 0.14 \mathrm{~N} \mathrm{~cm}^{-2}\right)$ when deacetylation 
Table I. Bonding strength of the DNA-chitosan membrane to rabbit peritoneum

\begin{tabular}{|c|c|c|}
\hline Sample $^{\mathrm{a}}$ & $\frac{\text { Chitosan-side adhesion }}{\mathrm{N} \mathrm{cm}^{-2}}$ & $\frac{\text { DNA-side adhesion }}{\mathrm{N} \mathrm{cm}^{-2}}$ \\
\hline DNA-chitosan 62 membrane & $0.06 \pm 0.03$ & $0.05 \pm 0.03$ \\
\hline DNA-chitosan 70 membrane & $0.32 \pm 0.07$ & $0.09 \pm 0.06$ \\
\hline DNA-chitosan 80 membrane & $0.47 \pm 0.14$ & $0.11 \pm 0.03$ \\
\hline $\begin{array}{l}\text { Chitosan } 80 \text { membrane } \\
\overline{\text { Fibrin }} \overline{\text { glue }}-{ }_{-}-{ }_{-}\end{array}$ & $-\frac{0.46 \pm 0.23}{0.53 \pm 0.06}-$ & \\
\hline
\end{tabular}

Bonding strength $\left(\mathrm{N} \mathrm{cm}^{-2}\right)$ were expressed by an average of 5 measurements (means \pm S.D.). ${ }^{a}$ Number indicates deacetylation degree of chitosan.

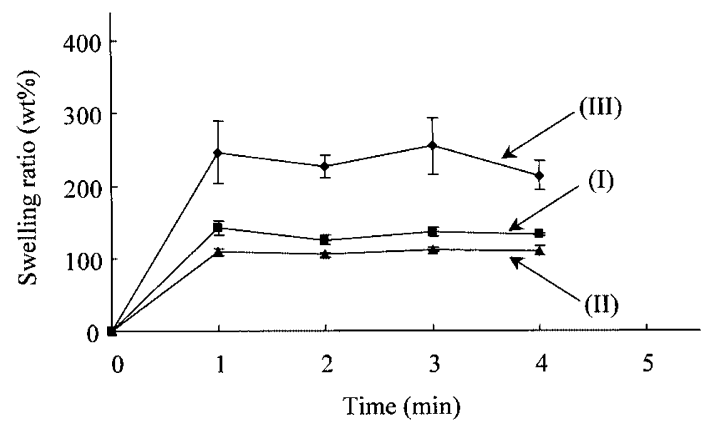

Figure 6. Swelling ratio of membranes. The membranes were dried under vacuum and the dry weight was measured. After immersing in ultra pure water, wet weight was measured. Swelling ratio of the membranes was calculated from the equation (a). Amount of DNA, (I): $0.3 \mathrm{mg} \mathrm{cm}^{-2}$, (II): $0.4 \mathrm{mg} \mathrm{cm}^{-2}$, (III) chitosan membrane. The swelling ratio was expressed by an average of 3 measurements (means \pm S.D.).

degree of chitosan increased $(62-80 \%$ deacetylation). The bonding strength of the chitosan-side $\left(0.47 \pm 0.14 \mathrm{~N} \mathrm{~cm}^{-2}\right)$ of DNA-chitosan 80 membrane was comparable with that of the chitosan 80 membrane $\left(0.46 \pm 0.23 \mathrm{~N} \mathrm{~cm}^{-2}\right)$. The bonding strength of the chitosan-side was similar to that of fibrin glue. While, DNA side of the bilayer membranes did not adhere to the peritoneum. Chitosan is cationic and tissues are usually anionic. The interactions between chitosan and tissues seem to be mainly involved in electrostatic attractions. ${ }^{23,24}$ In contrast, DNA is anionic and may not adhere to anionic tissues. The surface structure of the chitosan-side is smooth but the DNAside is fiber-like. The surface structure may also play a critical role for the bonding strength. The bonding strength of the chitosan-side was found to be depending on the deacetylation degree. Highly deacetylated chitosans may have higher bonding strengths. However, more than $80 \%$-deacetylated chitosan may show toxicity. ${ }^{2,6}$ For this reason, we used $80 \%$ deacetylated chitosan in this study. Taken together, the DNA-chitosan 80 membrane is suggested to have a potential to serve as a bi-functional bio-adhesive.

Here, we designed a bilayer membrane consisting of chitosan and DNA (Figure 7). The DNAchitosan bilayer membranes consisting of DNA- and

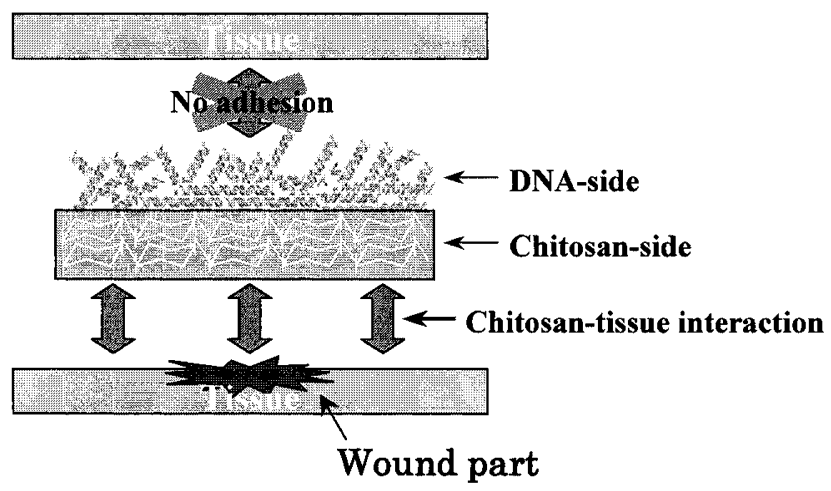

Figure 7. Model of DNA-chitosan bilayer membrane as a bifunctional biomedical adhesive. The chitosan-side of the bilayer membrane could strongly adhere to tissues and may promote wound healing. The DNA-side may not attach to tissues and eliminate nonspecific adhesions.

chitosan- surfaces were successfully prepared using UV-irradiated DNA membranes $\left(0.3-0.5 \mathrm{mg} \mathrm{cm}^{-2}\right)$ and chitosan $\left(2.0 \mathrm{mg} \mathrm{cm}^{-2}\right)$. Chitosan membrane adheres to tissues. ${ }^{23,24}$ Chitosan is cationic and tissues are usually anionic. The interactions between chitosan and tissues seem to be mainly involved in electrostatic attractions. In contrast, DNA is anionic and may not adhere to anionic tissues. The chitosan-side of the bilayer membrane could strongly adhere to tissues and may promote wound healing. ${ }^{7}$ The DNA-side may not attach to tissues. If the bilayer membrane is applied to the intraperitoneal adhesion, the chitosan-side adheres tissues and the DNA-side eliminates non-specific adhesions. Additionally, the DNA layer retained the double stranded structure. When the bilayer membrane was incubated with ethidium bromide, the DNA-side was stained with ethidium bromide but the chitosanside was not (Figure 8). These results indicate that the DNA-side of the DNA-chitosan bilayer membranes retain the double stranded structure. The specific property of DNA of the bilayer membrane can be used as a drug carrier or reservoir. The DNA-chitosan bilayer membrane has various advantageous and a potential to serve as a bi-functional bio-adhesive for therapeutic application. 

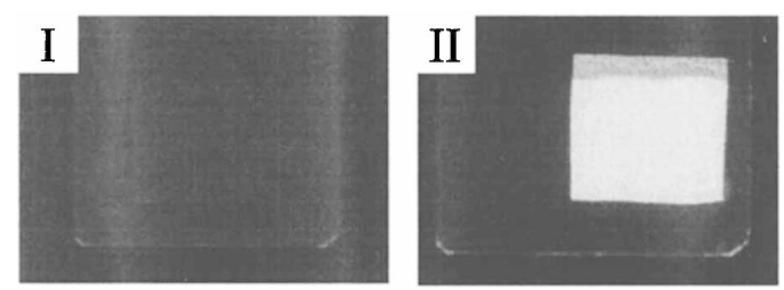

Figure 8. Ethidium bromide staining of chitosan membrane and DNA-chitosan membrane. The membranes $\left(1 \times 1 \mathrm{~cm}^{2}\right)$ were immersed in ultra pure water and stained by ethidium bromide $\left(20 \mu \mathrm{g} \mathrm{mL}^{-1}\right)$ for $24 \mathrm{~h}$. The membranes were observed under UV illumination. (I) The chitosan alone membrane. (II) The DNA-side of the DNA-chitosan membrane. The DNA-side was stained with ethidium bromide but chitosan-side was not.

Acknowledgments. The authors wish to thank Dr. A. Fujita, Mrs. Y. Motoyashiki, and Mr. H. Yamada, Medical Research \& Development Group, Kuraray Co. Ltd., Kurashiki, Okayama 710-0801, Japan. This work was supported by the Grants-in-Aid for Scientific Research from the Ministry of Education, Culture, Sports, Science and Technology of Japan (No.11694114, No.11450359, No.10555327, No.13132201, and No.14350491) and also by Hokkaido Foundation for the Promotion of Scientific and Industrial Technology (Hokscitec).

\section{REFERENCES}

1. R. A. A. Muzzarelli, Ed., "Chitin”, Pergamon Press, New York, N.Y., 1977.

2. S. Minami, Y. Okamoto, K. Hamada, Y. Fukumoto, and Y. Shigemasa, in "Chitin and Chitinases", 2nd ed., P. Jollès and R. A. A. Muzzarelli, Ed., Birkhäuser Verlag, Basel, 1999, p 265.

3. S. B. Rao and C. P. Sharma, J. Biomed. Mater. Res., 34, 21 (1997).

4. T. Tanigawa, Y. Tanaka, H. Sashiwa, H. Saimoto, and Y. Shigemasa, in "Advances in chitin and chitosan", 2nd ed., C. J. Brine, P. A. Sandford, and J. P. Zikakis Ed., Elsevier
Science Inc., New York, N.Y., 1992, p 206.

5. Y. Okamoto, M. Nose, K. Miyatake, J. Sekine, R. Oura, Y. Shigemasa, and S. Minami, Carbohydr. Polym., 44, 211 (2001).

6. B. C.-Gómez and R. Duncan, Int. J. Pharm., 148, 231 (1997).

7. S. Hirano, in "Biotechnology annual review", 2nd ed, M. R. El-Gewely, Ed., Elsevier Science Inc., New York, N.Y., 1996, vol.2, p 237.

8. M. Yamada, K. Kato, M. Nomizu, N. Sakairi, K. Ohkawa, H. Yamamoto, and N. Nishi, Chem. Eur. J., 8, 1407 (2002).

9. M. Yamada, K. Kato, M. Nomizu, K. Ohkawa, H. Yamamoto, and N. Nishi, Environ. Sci. Technol., 36, 949 (2002).

10. S. Matsuda, H. Iwata, N. Se, and Y. Ikada, J. Biomed. Mater. Res., 45, 20 (1999).

11. K. Ono, Y. Saito, H. Yura, K. Ishikawa, A. Kurita, T. Akaike, and M. Ishihara, J. Biomed. Mater. Res., 49, 289 (2000).

12. T. Matsumoto, R. M. Hardaway, K. C. Pani, and P. M. Margetis, Am. Surgeon., 34, 263 (1968).

13. Y.-C. Tseng, S.-H. Hyon, Y. Ikada, Y. Shimizu, K. Tamura, and S. Hitomi, J. Appl. Biomater., 1, 111 (1990).

14. H. G. Borst, A. Haverish, G. Walterbusch, and W. Maatz, $J$. Thorac. Cardiovasc. Surg., 84, 548 (1982).

15. O. Thetter, Thorac. Cardiovasc. Surgon, 29, 290 (1981).

16. J. A. Rousou, R. M. Engelman, and R. H. Breyer, Ann. Thorac. Surg., 38, 409 (1984).

17. O. J. Moy, C. A. Peimer, M. P. Koniuch, C. Howard, M. Zielezny, and P. R. Katikaneni, J. Hand. Surg., 13A, 273 (1988).

18. C. Remunán-López, A. Portero, J. L. Vila-Jato, and M. J. Alonso, J. Controlled. Release., 55, 143 (1998).

19. N. Özmeriç, G. Özcan, C. M. Haytaç, E. E. Alaaddinoglu, and M. F. Sargon, J. Biomed. Mater. Res., 51, 500 (2000).

20. F.-L. Mi, Y.-B. Wu, S.-S. Shyu, J.-Y. Schoung, Y.-B. Huang, Y.-H. Tsai, and J.-Y. Hao, J. Biomed. Mater. Res., 59, 438 (2002).

21. W. Wang, S. Bo, S. Li, and W. Qin, Int. J. Biol. Macromol., 13, 281 (1991).

22. J. D. Smith and R. Markham, Biochem. J., 46, 509 (1950).

23. C.-M. Lehr, J. A. Bouwstra, E. H. Schacht, and H. E. Junginger, Int. J. Pharm., 78, 43 (1992).

24. P. He, S. S. Davis, and L. Illum, Int. J. Pharm., 166, 75 (1998). 